\title{
Syed Ameer Ali: Muslim Rationalist in the 19th Century (Syed Ameer Ali: Tokoh Rasionalisme dalam Dunia Islam Abad ke-19)
}

\author{
Md Hasri B. Rajali \\ Pusat Pengajian Ilmu Kemanusiaan, Universiti Sains Malaysia \\ Corresponding email: hasrirajali@gmail.com
}

Article history

Received: 2016-03-13

Received in revised form: 2017-08-09

Accepted: 2017-08-09

\begin{abstract}
The spirit of rationalism is often adopted by the group of Western-educated Muslim intellegensia. Furthermore, it became popular in the 19th century as was the case in India namely Syed Ameer Ali, one of the figures who advocate the spirit of rationalism. Syed Ameer Ali had been said to have made the philosophy of rationalism as the principle of his life in fighting for the true meaning of Islam. It also aims to rescue the Muslims from the rut of the realm of intellectual lethargy and emulate the intellectual awakening epitomized by the Abbasid empire. Therefore, this paper will discuss Syed Ameer Ali's idea of discourse on Islamic thought based on his great works.
\end{abstract}

Keywords: Syed Ameer Ali, Rasionalism, Modernism, Mu'tazila.

\begin{abstract}
Abstrak
Semangat rasionalisme ini sering kali diguna pakai oleh golongan inteligensia Islam yang berpendidikan Barat. Tambahan pula, ia mula popular pada abad ke-19 seperti mana yang berlaku di India yakni Syed Ameer Ali salah satu tokoh yang melaungkan semangat rasionalisme. Syed Ameer Ali dikatakan telah menjadikan falsafah rasionalisme sebagai prinsip kehidupannya bagi memperjuangkan pengertian Islam yang sebenar. Ini bertujuan untuk menyelamatkan umat Islam daripada kelesuan dunia intelektual dan mencontohi kebangkitan intelektual sepertimana yang dibawa dalam kerajaan Bani Abbasiyah. Oleh itu, makalah ini akan membahaskan wacana idea Syed Ameer Ali terhadap pemikiran Islam bersumberkan karya-karya agung beliau.
\end{abstract}

Kata Kunci: Syed Ameer Ali, rasionalisme, modernisme , mu'tazilah 


\subsection{PENDAHULUAN}

Dalam sejarah dunia, falsafah rasionalisme sering kali dikaitkan dengan dunia Barat khususnya dengan kemunculan tokoh-tokoh Yunani klasik seperti Pythagoras (570-495 S.M.), Plato (427-347 S.M.), dan Aristotle (384-322 Sebelum Masihi). Menurut Guthrie (2002 :2), falsafah rasionalisme ini dapat difahami sebagai suatu kaedah dan teori intrepretasi. Beliau menyebut:

First, rationalism can be perceived as a methodology about how people can access the external world. Secondly, rationalism can be perceived as a theory of interpretation. That is, rationalism is used to justify our collective knowledge by seeking to provide a sure foundation.

Daripada sudut epistemologi, rasionalisme bermakna keupayaan akal manusia untuk menjelaskan sesuatu sebab-musabab secara rasional. Ia juga merupakan falsafah yang digunakan untuk memahami sifat perkara (nature) dengan menjelaskan sebab-musabab perkara tersebut. Tambahan pula fundamental rasionalisme juga memerlukan kefahaman yang rasional dan berunsur deduktif. Oleh itu, prinsip rasionalis boleh menjelaskan persoalan matematik, etik dan metafizik secara logik. Armour \& Bradley (1996: 98) menjelaskan:

The philosophical view that regards reason as the chief source and test of knowledge...itself has an inherently logical structure.

Hal ni bermakna kaum rasionalis ini menjadikan akal sebagai asas dan sumber pengetahuan mereka. Dalam konteks ini, mereka berpendapat bahawa mereka akan menghasilkan pengetahuan yang tidak boleh diragukan dan absolute (Nasution,1995). Oleh itu secara umumnya, falsafah rasionalisme ini hanyalah suatu kaedah yang saintifik untuk memahami asas penyebab sesuatu fenomena, perlakuan, tindakan dan sebagainya. Bahkan pada abad ke-19 Masihi di Eropah, falsafah rasionalisme ini mengalami krisis intelektual dengan golongan empirikalisme khususnya soal perbahasan metafizik. Bennett (2015: 3) mengatakan:

"Rationalism" has variously been taken to mean "the scientific quest for the knowable" or "an empirical approach to understanding the world" characteristic of nineteenthcentury freethinkers.

Dalam dunia Islam telah wujud dua reaksi terhadap falsafah rasionalisme ini. Reaksi pertama menyatakan falsafah rasionalisme ini diambil dan dipinjamkan oleh tamadun Islam daripada tamadun Yunani Greek seperti mana yang dinyatakan oleh F. R. Rosenthal (Fjordman, 2007: 1); sebaliknya reaksi kedua memberi pandangan yang berbeza dan menyakini bahawa falsafah rasionalisme ini sememangnya sudah wujud sejak zaman Abbasiyah lagi kemudiannya dipinjam kepada tamadun Eropah (Kassim Ahmad, 1985: 6). Malah, ia digunakan untuk mentafsirkan perkara-perkara yang melibatkan Islam selagi bersandarkan kepada wahyu Tuhan dan sunnah Nabi. Selepas kewafatan Nabi Muhammad, muncul pelbagai aliran umpamanya aliran $\mathrm{Mu}$ 'tazilah yang dikenali sebagai "kaum rasionalis Islam" dalam sejarah pemikiran Islam (Nasution, 2013: 40). Hal ini kerana aliran ini membawa persoalan-persoalan teologi yang bersifat falsafah dengan bersandarkan kepada akal sebagai alat penyelesaian tersebut.

Abad ke-19 merupakan zaman kolonialisme menguasai hampir seantero dunia. Pada abad tersebut, umat Islam mengalami kemunduran selepas keruntuhan kerajaan Turki Uthmaniyyah yang sebelumnya menjadi benteng pemikiran umat Islam seluruh dunia sama ada daripada sudut politik, ekonomi, dan sosial. Jika sebelum itu aliran Mu'tazilah hanya membahaskan soal-soal teologi semata-mata, namun pada zaman yang baharu ini, mereka juga mempersoalkan isu-isu politik, sosial dan ekonomi supaya umat Islam tidak ketinggalan dalam pembangunan. Oleh itu salah satu ciri-ciri kesinambungan yang dibawa oleh mereka adalah pengagungan kepada akal (rasionalisme) untuk menjawab persoalan-persoalan yang berhubung dengan perkara-perkara teologi, sosial, politik dan hukum hakam agama.

Contoh isu yang difokuskan oleh penganut $\mathrm{Mu}$ 'tazilah antaranya ialah mengenai perletakan akal dalam sumber pengetahuan manusia. Menurut al-Syahrastani,salah seorang penganut $\mathrm{Mu}$ 'tazilah, segala 
pengetahuan dapat diperolehi selagi mana menggunakan akal rasional sebaik mungkin (al-Syahrastani, t.t.: 42). Oleh itu, aliran $\mathrm{Mu}$ 'tazilah ini boleh dikatakan satu-satunya aliran dalam Islam yang mengagungkan akal selain wahyu Tuhan seperti al Quran. Di India, salah seorang tokoh Islam yang cenderung kepada pemikiran Mu'tazilah atau rasionalis Islam ini ialah Syed Ameer Ali (1849-1929).

Oleh itu, sebelum membahaskan pemikiran rasionalisme beliau tentang konsep Islam, terlebih dahulu makalah ini mensusur galurkan sub latar belakang tokoh ini secara lebih mendalam. Ini bertujuan untuk melihat apakah faktor situasional yang menyebabkan pembentukan pemikiran rasionalisme dalam diri Syed Ameer Ali pada awal abad ke-19 Masihi.

\subsection{RINGKASAN LATAR BELAKANG SYED AMEER ALI}

Syed Ameer Ali lahir pada 6 April 1849 di Cuttack, India. Beliau merupakan salah seorang daripada ahli perundangan dan juga seorang penulis yang terkenal di India. Pada tahun 1869, beliau telah mendapat pendidikan formal di Inner Temple, England (Abdul Rahman, 1987: 118). Selepas empat tahun kemudian seusai menamatkan pelajaran, beliau terus dilantik sebagai salah seorang pegawai British semasa pemerintahan kolonial British di India. Setelah itu, beliau melanjutkan pengajian sarjana dalam bidang perundangan di Universiti Calcutta. Pada tahun 1877, beliau menubuhkan National Mohammedan Association. Penubuhan persatuan tersebut bertujuan untuk memberikan pendedahan sistem pemerintahan Barat terhadap kaum Muslim di India pada ketika itu. Ini bermakna beliau menggunakan pengalaman beliau semasa berada di universiti dan di London pada tahun 1873 untuk mempelajari sistem pemerintahan Barat supaya dapat dipraktikkan di Calcutta, India. Setelah itu, beliau dilantik sebagai hakim di Mahkamah Tinggi Calcutta pada tahun 1890an (Nasution, 1975).

Sebagai salah seorang pegawai yang berpendidikan tinggi di India, beliau juga membantu proses pengundian yang pertama di kawasan beliau pada tahun 1909. Selain itu, beliau juga turut menubuhkan British Red Crescent Society bagi menjaga kebajikan umat Islam yang memerlukan. Bagi merapatkan jurang kefahaman orang Barat terhadap peradaban Islam pada waktu itu, beliau menulis karya-karya berkenaan dengan sejarah dan peradaban Islam dalam bahasa Inggeris. Antaranya, A Critical Examination of the Life and Teachings of Mohammed yang diterbitkan pada tahun 1873 merupakan buku beliau yang pertama semasa beliau tinggal di England dan juga buku-buku yang lain seperti The Personal Law of Muhammedans (1880), The Spirit of Islam (1891), Ethics of Islam (1893), Islam (1906), The Legal Position of Women in Islam (1912), dan A Short History of Saracens (1898). Pada tahun 1904, beliau menjadi penduduk tetap di England dan menjawat jawatan sebagai ahli perundangan pada tahun 1909 kemudiannya, meninggal pada 3 Ogos 1928 di Sussex, England.

Tidak syak lagi, berdasarkan latar belakang beliau sekitar tahun 1969 hingga tahun 1973, menunjukkan beliau terpengaruh dengan tradisi intelektual Barat. Ini dibuktikan menerusi kenyataankenyataan yang kontroversi daripada nukilan-nukilan karyanya sendiri seperti $A$ Critical Examination of the Life and Teachings of Mohammed pada tahun 1873 yang jelas menunjukkan bahawa beliau mengangkat tradisi rasionalisme kemudiannya dipadatkan dalam tradisi Islam klasik khususnya di India pada waktu itu. Malah pengagungan rasionalisme itu memberi anggapan bahawa Nabi Muhammad sebenarnya membawa perwatakan rasionalisme sebenar dalam dunia Islam (Ameer Ali, 1906: 29-30).

Oleh itu, pemikiran beliau sama ada betul atau tidak, seharusnya dibincangkan daripada sudut wacana idea yang telah dilontarkan terhadap dunia Islam. Hal ini kerana wacana idea tersebut telah memberikan impak pemikiran dalam sejarah Islam khususnya di India. Dalam kerangka pemikiran tersebut, beliau berusaha untuk memodernisasi pemikiran umat Islam di India pada tempoh tersebut. Lantaran itu, sub topik seterusnya menganalisis wacana-wacana pemikiran Syed Ameer Ali yang bercorak rasionalisme terhadap Islam. 


\subsection{RASIONALISME DALAM KONSEP ISLAM}

Dalam sub topik ini, perbahasan Syed Ameer Ali tentang konsep Islam difokuskan kepada isu-isu yang tertentu yakni pendefinisian Islam, dunia akhirat dan poligami. Walaupun terdapat isu-isu lain, ketiga-tiga isu ini dipilih kerana bersandarkan kepada nukilan-nukilan karya Syed Ameer Ali sendiri.

\subsection{ISLAM}

Menurut Syed Ameer Ali, Islam itu bermakna keamanaan, kedamaian dan penyerahan kepada Tuhan. Definisi penyerahan kepada Tuhan disini tidak berhubung kait dengan mana-mana idea fatalisme. Bagi beliau, manusia itu sebagai agen yang bebas sebagaimana makhluk lain tetapi mempunyai limitasi sama ada dari sudut masa dan lokasi. Hal ini kerana hanya Tuhan sahaja yang tidak mempunyai limitasi terhadap dua sifat tersebut.

The Meaning of Islam-Islam is the name which the followers of the Arabian Prophet give their religion. It mean peace, greeting, safety, salvation. It does not involve, however, any idea of fatalism. In its ethical sense it signifies striving after righteousness. Man is a free agent within his limited sphere: the ordinance of God lay down the eternal principles of human conduct (Ameer Ali, 1906: 3-4).

Dalam hal ini juga bermakna Syed Ameer Ali sebenarnya mengkritik masyarakat Islam pada masa itu yang terlalu taksub terhadap fatalisme atau takdir Bagi Syed Ammer Ali, manusia sendiri yang mencipta perbuatan-perbuatannya sendiri bukannya Tuhan. Hal ini kerana, Tuhan memberikan dua pilihan terhadap setiap manusia yakni kuasa baik dan kuasa jahat sama ada membawa manusia itu kepada Dia ataupun menyimpang daripada Dia. Oleh itu, manusia ialah makhluk yang dapat bebas memilih sama ada baik mahupun jahat tanpa ada sekatannya daripada Tuhan.

He has pointed out two out courses- the one leading away from Him, and that is evil; the other bringing man to Him, and that is good. Every individual is free to choose and follow whichever courses he likes, and receives his deserts accordingly (Ameer Ali, 1906: 3-4).

Sekali lagi, Syed Ameer Ali mengulas kedudukan manusia:

Man, within the limited sphere of his existence is absolute master of his conduct. He is responsible for his actions and for the use or misuse of the powers with which he has been endowed. He may fall or rise according to his own "inclination" (Ameer Ali, 1906: 407).

Dalam soal ini, Syed Ameer Ali sering kali menjadikan Nabi Muhammad sebagai hujah untuk mempertahankan Islam itu bukannya ajaran yang berfahaman fatalisme. Bagi beliau, suasana masyarakat di Tanah Semenanjung Arab pada ketika itu diselubungi perkara-perkara yang jahil. Bahkan, kepercayaan masyarakat pada waktu itu kebanyakannya menyembah berhala dan mempercayai sesuatu yang mistik. Oleh itu, kedatangan Nabi Muhammad sebenarnya membawa perwatakan yang rasionalisme dan saintifik terhadap masyarakat Arab yang dibelunggu kejahilan setelah sekian abad" (Ameer Ali, 1906: 29-30). Sepertimana penyair Islam yang terkenal, Muhammad Iqbal menyatakan sumber wahyu menyatakan Nabi Muhammad adalah milik dunia purba sebaliknya, roh wahyu menyatakan beliau adalah milik dunia moden sebenarnya.

Prophet Muhammad however according to the Quran, had no miracles. Opening the modern era to mankind, he must appeal through knowledge and reason (Kassim Ahmad, 2012: 55).

Pandangan Muhammad Iqbal, Kassim Ahmad dan sebahagian sarjana Islam yang lain hampir sama dengan Syed Ameer Ali dalam soal kewujudan dan keberadaan Nabi Muhammad dalam dunia Islam. Bagi beliau, kenabian Nabi Muhammad bersandarkan kepada rasional dan intelektual kerana tidak wujud satu pun perkara ajaib yang dilakukan oleh baginda melainkan menjadikan Quran sebagai panduan dakwah baginda (Ameer Ali, 1902: 31). Oleh itu, kehadiran Nabi Muhammad hanyalah sebagai manusia semata-mata bukannya dewa mahupun tuhan yang kekal kerana sejak lahir baginda telah menunjukkan 
kepada umat manusia pengertian kegigihan untuk mencapai matlamat (Ameer Ali, 1902: 33). Misalnya, sebelum diwahyukan, baginda sendiri mencari rezeki dengan mengembala kambing dan berdagang untuk menampung ekonomi keluarga baginda. Selepas diwahyukan, baginda sendiri juga berdakwah selama 13 tahun tanpa bantuan sesiapa pun melainkan dengan mukjizat Tuhan yakni al-Quran.

\subsection{SISTEM POLIGAMI}

Salah satu kritikan sarjana Barat terhadap Islam adalah mengenai sistem poligami yang diamalkan oleh Nabi Muhammad. Bagi Syed Ameer Ali, sistem poligami sudah diamalkan sebelum kedatangan Nabi Muhammad lagi. Hal ini kerana kebanyakan negara di Timur pada ketika itu mengamalkan sistem poligami khususnya dalam kalangan kerabat diraja (Ameer Ali, 1902:183). Anggapan para penulis Kristian terhadap Nabi Muhammad menceduk sistem poligami lalu melegitimasikan sistem tersebut dalam Islam adalah tidak benar. Hal ini kerana sistem poligami tersebut juga ada dalam kalangan umat Kristian dan menjadi undang-undang adat dalam masyarakat Arab, malahan juga dalam kalangan masyarakat di luar tanah Semenanjung Arab pada waktu itu (Ameer Ali, 1902: 187; 1906: 29-30).

Maka, dengan kemunculan Nabi Muhammad, baginda telah mempertahankan hak wanita dan meletakkan kedudukan mereka sama tinggi dengan lelaki. Disebabkan amalan poligami sudah menjadi budaya pada zaman tersebut, Nabi Muhammad berusaha untuk mengekang sistem poligami dengan menghadkan bilangan maksimum perkahwinan pada ketika itu (Ameer Ali, 1902: 189). Syed Ameer Ali berpendapat pada akhirnya keperluan sistem poligami ini juga akan hilang mengikut peredaran zaman kecuali bagi golongan wanita yang benar-benar memerlukannya sebagai perlindungan kehidupan (Ameer Ali, 1880: 225- 278).

With the progress of thought, with the ever-changing conditions of this world, the necessity for polygamy disappears, and its practice is tacitly abandoned or expressly forbidden. And hence it is, that in those Moslem countries where the circumstances which made its existence at first necessary are disappearing, plurality of wives has come to be regarded as an evil, and as an institution opposed to the teachings of the Prophet; while in those countries where the conditions of society are different, where the means which, in advanced communities, enable women to help themselves are absent or wanting, polygamy must necessarily continue to exist (Ameer Ali, 1902: 190-191).

Menurut Islam, hak wanita untuk berkahwin ataupun tidak berkahwin tetap sama dan tidak akan mengubah status dan kapasitinya sebagai wanita yang merdeka. Bagi Syed Ameer Ali, isteri seorang Muslim boleh mendapat harta perwarisan daripada peninggalan ibubapa dan juga kaum kerabatnya. Hal ini menunjukkan bahawa perkahwinan itu adalah suatu institusi yang menjaga hak wanita daripada manamana penindasan masyarakat khususnya daripada sudut ekonomi yang secara tidak langsung dapat menghindari mereka daripada perkara yang keji.

Marriage made no difference in their status or capacity. And a Mussulman wife became as competent to hold property and make dispositions as a single woman. Nor were they denied a share in the patrimony of their parents or kinsfolk in favour of their male relations. Marriage was declared to be an institution ordaines that human beings may guard themselves from foulness and unchastity (Ameer Ali, 1906: 29).

\subsection{KONSEP DUNIA AKHIRAT}

Bagi Syed Ameer Ali, faktor geografi juga turut mempengaruhi kepercayaan dan keyakinan masyarakat pada zaman dahulu. Misalnya, masyarakat di tanah Semenanjung Arab pada waktu itu tinggal dalam suasana geografi yang berpadang pasir dan gersang. Oleh itu, mereka dikatakan memerlukan sesuatu yang realistik untuk kehidupan mereka. Justeru, mereka mengambil intisari daripada ajaran palsu yang terdahulu seperti ajaran Zoroaster, Sabien, dan sebagainya. 
There is no doubt that in the Suras of the intermediate period, before the mind of the Teacher had attained the full development of religious consciousness, and when it was necessary to formulate in language intelligible to the common folk of the desert, the realistic descriptions of heaven and hell, borrowed from the floating fancies of Zoroaster, Sabaen, and the Talmudical Jews, attract the attention as a side picture, and then comes the real essence-the adoration of God in humility and love (Ameer Ali, 1902: 236).

Bagi beliau, konsep syurga dan neraka ini tidak muncul dalam kepercayaan penganut Yahudi pada peringkat awal. Hal ini termasuklah konsep ganjaran dan hukuman yang sebenarnya telah dibawa oleh tamadun Babylon dan kemudiannya mempengaruhi fikiran masyarakat Yahudi. Tambahan pula, masyarakat Yahudi juga mengambil konsep kepercayaan syurga dan neraka daripada penganut Zoroastrian Bihast dan Duzakh (Ameer Ali, 1906: 12-13). Menurut kepercayaan penganut Zoroastrian Bihast, syurga itu dipanggil sebagai hooris yang dipercayai mampu dilihat dengan kuasa pancaindera. Syed Ameer Ali mendakwa fahaman ini telah menular dalam kalangan masyarakat Nasrani dan juga masyarakat Islam yang memahami bahawa syurga dan neraka adalah suatu tempat fizikal yang wujud setelah manusia meninggal dunia. Beliau menggelarkan mereka sebagai golongan literalis kerana memahami ayat Quran secara literal dan menceduk kepercayaan masyarakat sebelum ini.

The hooris are creatures of Zoroastrian origin, so is paradise, whilst hell in the severity of some places almost sensuous; but they are sensual, or that Mohammed, or any of his follower, even the ultra-literalists accepted them as such, is a calumny (Ameer Ali, 1902: 197).

Ini bermakna Syed Ameer Ali menganggap aliran Mu'tazilah mempunyai pandangan yang berbeza dengan aliran literalis terhadap konsep syurga dan neraka. Pemahaman ini berbeza pula disebabkan oleh tafsiran realistik terhadap istilah syurga dan neraka seperti yang dinyatakan dalam al- Quran. Hal ini

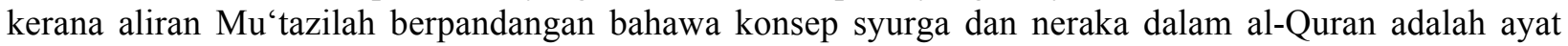
mutashabihat bukannya ayat muhkamat. Dalam hal ini, pemikiran tersebut membahaskan neraka dan syura sebagai suatu bentuk keadaan mentaliti manusia. Dengan kata lain, syurga itu bermaksud keadaan mental manusia yang sihat dan bahagia, sebaliknya neraka itu bermaksud keadaan mental manusia yang sakit dan menyeksakan. Pengertian ini jelas menunjukkan bahawa Syed Ameer Ali berpandangan bahawa konsep syurga dan neraka dalam Quran adalah suatu konsep alegori terhadap keadaaan mentaliti manusia sebenar di dunia. Namun begitu, beliau mempercayai bahawa apabila manusia meninggal dunia, roh akan kembali kepada Universal Soul (Tuhan).

Another section looks upon the joys and pains of the Hereafter as entirely subjective. It holds that as extreme mental pain is far more agonizing than physical pain, so is mental pleasure of the higher type far more rapturous than any sensuous pleasure; that as, after physical death, the individual soul returns, to use Koranic expression, to the Universal Soul, all the joys and pains, portrayed in vivid colours by the inspired Teacher to enable the masses to grasp the truth, will be mental and subjective (Ameer Ali, 1902: 200).

Dalam konteks ini, Syed Ameer Ali berpandangan bahawa gambaran dunia akhirat dalam Quran itu sepertimana yang difahami oleh golongan literal ini hampir sama dengan kefahaman masyarakat yang mempercayai kitab New Gospel. Kepercayaan seperti ini hampir mempengaruhi kebanyakan umat Islam yang membayangkan keindahan dan keseronokan dunia lain (Ameer Ali, 1906: 14). Tambahan pula, kebanyakan muslim mempercayai bahawa adanya hari kebangkitan (resurrection), manakala sebahagian lain seperti aliran $\mathrm{Mu}$ 'tazila menolak adanya hari kebangkitan disebabkan tidak ada sebab wujudnya Hari Kebangkitan. Walaupun berbeza dalam hal tersebut, setiap muslim mempercayai bahawa semua roh manusia akan dinilai secara adil oleh Tuhan (Nasution, 2013: 123-128).

As in Christianity, some Moslems believe in corporeal resurrection, other do not. Some believe that God can be seen by corporeal sight, others entirely deny it. But all believe that when the human souls are gathered up in the Great Account, the Divine Presence will enfold the Universe (Ameer Ali, 1906: 20). 


\subsection{PEMIKIRAN ISLAM YANG RASIONAL: PANDANGAN SYED AMEER ALI}

Daripada konsep yang telah dibahaskan sebelum ini, ternyata Syed Ameer Ali adalah salah seorang peminat falsafah rasionalisme yang tegar. Hal ini kerana beliau melihat pertembungan kontroversi antara tamadun Greek dan bangsa Saracens yang telah bersaing untuk mencapai kemajuan intelektualisme pada ketika itu (Ameer Ali, 1902: 336). Bangsa Saracens yang mewakili tamadun Islam pada waktu itu berusaha untuk mempelajari dialek dan falsafah Greek. Oleh itu, muncullah beberapa orang tokoh Saracens yang memperkenalkan ilmu falsafah tersebut dalam kalangan masyarakat Islam antaranya Jaafar as-Siddiq. Oleh itu, ilmu falsafah yang bersifat rasionalisme dan saintisme mula tersebar dalam tamadun Islam selepas itu.

Ali's great-grandson, Jaafar the Trusty, who died in 765 A.C. He is the real founder of speculative philosophy among the Moslems. The thinkers and scholars who flourished later derived their inspiration from him (Ameer Ali, 1906: 71).

Bagi Syed Ameer Ali, Harun al-Rashid, khalifah kelima kerajaan Abbasiyyah adalah salah seorang pemimpin yang bertanggungjawab meningkatkan pemikiran rasionalisme dalam tamadun Islam. Oleh itu, beliau mengelarkan Harun al-Rashid sebagai 'hero of the Arabian Nights'. Hal ini kerana baginda telah berjaya meningkatkan budaya intelektualisme dalam kalangan muslim pada waktu tersebut. Bahkan, sumbangan muslim dalam pelbagai bidang diiktiraf seantero dunia sehingga melintasi sempadan Mesir dan Asia Barat (Ameer Ali, 1906: 69). Oleh itu, kemuncak kepada pemikiran yang bersifat rasionalisme dan saintisme ini tetap berkembang khususnya semasa zaman pemerintahan al-Mutawakkil pada tahun 847 Masihi hingga 861 Masihi. Semasa Al-Mutawakkil menjadi khalifah dalam kerajaan Bani Abbasiyyah, baginda telah mengalakkan perkembangan ilmu khususnya ilmu rasionalisme. Oleh itu, kedudukan golongan rasionalis Islam pada zaman Abbasiyah dipandang tinggi dalam sistem pentadbiran.

When Mutawakkil was raised to the throne the position of the various parties stood thus: the Rationalists were the directing power of the state; they held the chief offices of trust...they represents the wisdom and the wealth of the empire; Rationalism was the dominating creed among the educated, the intellectual, and influential classes of the community (Ameer Ali, 1902: 439).

Syed Ameer Ali melihat aliran $\mathrm{Mu}$ 'tazilah adalah golongan rasional yang telah membawa tamadun Islam kepada pencapaian intelektualisme yang tinggi. Namun begitu, setiap aliran sudah tentu mempunyai percanggahan pandangan dalam soal-soal Islam seperti persoalan teologi, fiqh dan sebagainya. Menurut beliau, dalam sejarah Islam, antara sosok tokoh yang menentang pemikiran ini adalah Imam Ahmad Bin Hanbal semasa zaman kerajaan Abbasiyyah. Oleh itu, pemikiran Imam Ahmad disekat sementara setelah dipenjara oleh al-Mu'tashim. Bagi Syed Ameer Ali, Imam Ahmad merupakan seorang yang berpandangan literal dalam mentafsirkan al-Quran, menolak kebebasan manusia, dan dituduh menolak ilmu sains bagi menunjukkan penentangannya terhadap aliran rasionalisme pada zaman al-Mutawakkil.

Ibn Hanbal adopted the extreme Sifatia views; he inculcated that the Deity was visible to the human sight; that His attributes were separate from His essence; that the statements about His being seated on the throne were to be accepted in their literal sense; that man was in no sense a free agent; that every human action was the direct act of the Deity, and so forth. He denounced learning and science, proclaimed a holy war against Rationalism (Ameer Ali, 1902: 438-439).

Menerusi sumbangan kerajaan Bani Abbasiyyah tersebut, pada kurun ke-10, semangat eclecticism meningkat dalam kalangan ilmuwan Islam sehingga ke pelusuk dunia. Secara tidak langsung, ia membina ikatan intelektualisme dalam kalangan penyelidik Muslim di pelbagai kawasan dan bahagian dalam bidang ilmu. Hal ini menunjukkan bahawa Syed Ammer Ali cenderung kepada pemikiran Mu'tazila yang dibawa pada zaman Abbasiyah berbanding aliran literalis seperti yang dibahas oleh beliau sebelum ini. 
Tambahan pula, beliau melihat penekanan kepada falsafah rasionalisme ini akan membentuk moraliti manusia dan memperbanyakkan kebajikan intelektualisme dalam sesebuah negara.

Towards the close of the tenth century a body of thinkers, whose researches extended to every department of the human mind, and whose great aim was to introduction a spirit of eclecticism in Islam, established a brotherhood of intellect, which was to embrace all men animated with the single purpose of promoting the moral and intellectual welfare of the nation (Ameer Ali, 1906: 72).

Tambahan pula, Syed Ameer Ali melihat Khalifah Al-Mansur telah bertanggungjawab dalam memperbanyakkan usaha penterjemahan karya-karya sains dan kesusasteraan dalam bahasa asing seperti bahasa Syria, Greek, Byzantine dan Parsi ke dalam bahasa Arab. Bahkan, Khalifah Al-Mansur juga mempunyai banyak koleksi karya-karya asing dalam bidang astronomi, beberapa penulisan Aristotle, karya Claudius Ptolemy, Siddhania, Books of Euclid dan sebagainya yang telah diterjemah ke dalam bahasa Arab (Ameer Ali, 1902: 343). Karya-karya tersebut dipelajari dan dikaji bagi manfaat tamadun Islam. Secara tidak langsung ia mengalakkan umat Islam supaya berfikir secara rasional dan saintifik seperti mana yang difahami oleh Syed Ammer Ali. Malahan, beliau berpandangan bahawa buat pertama kalinya dalam sejarah umat manusia yang beragama, pihak pemerintah mendekatkan diri dan menyediakan institusi dalam bidang falsafah.

Dalam sejarah manusia, setiap masyarakat pada ketika itu sibuk dengan aktiviti sastera dan sains. Bahkan ada yang sanggup mengembara ke luar negara demi mencari ilmu khususnya di pusat-pusat ilmu seperti Cordova, Baghdad, dan Kaherah. Bahkan, pelajar Kristian dari setiap pelusuk Eropah juga pergi ke institusi tamadun Islam pada zaman tersebut. Namun begitu, dalam tamadun Islam, setiap institusi penyelidikan bersaing khususnya antara kerajaan Bani Abbasiyyah dengan kerajaan Fatimiyyah di Kaherah. Persaingan antara kedua buah kerajaan tersebut telah sampai ke peringkat kemuncak apabila kerajaan Fatimiyyah pada zaman pemerintahan al-Muiz li-din-illah telah menubuhkan universiti pertama dalam sejarah manusia iaitu Universiti al-Azhar pada tahun 975 Masihi.

The free university of Cairo, the Dar-ul-Hikmat Scientific Institute established by al-Muiz, 'anticipated Bacon's ideal with a fact.' The Idrisides at Fez, and the Moorish sovereigns in Spain, outvied each other in the cultivation of arts and letters. From the shores of the Atlantic eastward to the Indian Ocean, far away even to the Pacific, resounded the voice of philosophy and learning, under Moslem guidance and Moslem inspiration (Ameer Ali, 1902: 343-344).

Sebaliknya, pada waktu itu tamadun Eropah dilanda kejahilan kerana semasa pemerintahan Constantine misalnya pihak gereja telah menutup perpustakaan awam manakala penyelidikan sains dan sastera dimansuhkan. Hal ini menyebabkan pemikiran masyarakat Eropah pada masa itu mundur disebabkan sekatan oleh agama Kristian Ortodoks. Malahan, pihak gereja di Eropah menganggap bahawa pendidikan sains dan falsafah sebagai ilmu sihir yang mengancam kedudukan agama Kristian. Oleh itu, sesiapa yang mengajar dan mempelajari ilmu tersebut akan dihukum sebagaimana hukuman seorang pengkhianat agama. Ini berbeza dengan tamadun Islam pada tempoh tersebut yang amat mengalakkan kegiatan intelektualisme khususnya di pusat-pusat ilmu yang utama seperti Seville, Cordova, Granada, Murcia, dan Toledo. Namun begitu, zaman kegemilangan intelektualisme ini tidak kekal lama apabila bangsa Tartar telah menjajah dan memusnahkan pusat keilmuan dan ketamadunan Islam yang bersifat rasionalisme dan saintifik. Lantaran itu, tamadun Islam mula merudum dan pemikiran rasionalisme dalam kalangan masyarakat Islam kini juga telah mula pudar.

\subsection{KESIMPULAN}

Bersandarkan kepada karya-karya agung Syed Ameer Ali seperti Spirit of Islam Life and Teachings of Mohammed, Islam (1906), The Legal Position of Women in Islam (1912) dan A Short History of Saracens (1898) jelas menunjukkan bahawa beliau lebih cenderung kepada penekanan akal manusia dalam menjelaskan sebab-musabab sesuatu peristiwa dan tindakan manusia. Bagi Syed Ameer Ali, kekuatan akal inilah yang akan memandu manusia ke arah kemajuan dunia yakni sebuah syurga yang diingini oleh 
mereka. Hal ini selaras dengan konsep Islam yang difahami oleh beliau yang menolak fahaman fatalisme

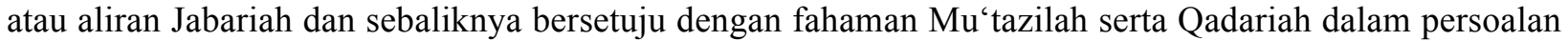
teologi. Oleh itu, dalam persoalan teologi, beliau meyakini bahawa peranan manusia amat penting untuk menentukan takdirnya sendiri sama ada kejayaan mahu pun kekalahan. Dalam soal ini, Tuhan tidak bertanggungjawab terhadap tindakan manusia, namun tidak menafikan bahawa tindakan manusia itu dibawah kendalian Pengetahuan Tuhan.

Dalam persoalan poligami pula, Syed Ameer Ali melihat sistem poligami itu adalah warisan sejarah yang diambil daripada masyarakat terdahulu sebelum kedatangan Nabi Muhammad lagi. Nabi Muhammad telah melakukan revolusi terhadap sistem poligami tersebut dengan menghadkan jumlah isteri yang boleh dinikahi. Secara tidak langsung, syarat-syarat perkahwinan poligami diperketatkan bagi menjaga kebajikan dan hak wanita dalam sistem perundangan Islam. Syed Ameer Ali menilai bahawa kepercayaan umat Islam terhadap wujudnya syurga dan neraka dalam bentuk fizikal sebenarnya dipengaruhi oleh tamadun-tamadun sebelum ini, sedangkan konsep ini dalam al-Quran merupakan alegori semata-mata yang mengambarkan keadaan psikologi manusia di dunia ini sama ada dalam bentuk bahagia (syurga) atau tersiksa (neraka). Akhir sekali, Syed Ameer Ali menganjurkan supaya umat Islam mencontohi sikap rasionalisme seperti masyarakat yang hidup pada zaman kerajaan Abbasiyah. Secara tidak langsung, beliau juga membahaskan mengenai kepentingan peranan pemerintah bagi memastikan budaya intelektualisme ini berkembang sepertimana dasar yang dilakukan oleh Khalifah Harun al-Rashid, Khalifah al-Ma'mun, Khalifah Mutawakkil dan lain-lain lagi. Wacana idea yang dibawa oleh Syed Ameer Ali telah mewujudkan fenomena baharu yang seolah-olah berusaha untuk membangkitkan pemikiran $\mathrm{Mu}$ 'tazilah pada abad ke-19. Hal ini diakui oleh Lothrop yang menyifatkan wacana idea Syed Ameer Ali telah melayakkan dirinya sebagai penganut $\mathrm{Mu}$ 'tazilah di India yang berpunca daripada desakan zaman tersebut yang cenderung terhadap fatalisme. Hal ini menyebabkan beliau muncul sebagai sosok tokoh yang memodernisasi sistem syariat Islam khususnya di India pada abad ke-19.

These men called themselves "Ne-Motazelites" and boldly advocated reforms such as a thorough overhauling of the sheriat and a general modernization of Islam (Stoddard, 1921: 38).

\section{Rujukan}

Abdul Rahman Abdullah. (1987). Pemikiran Islam Masa Kini: Sejarah dan Aliran. Kuala Lumpur: Dewan Bahasa dan Pustaka.

Abrahamov, Binyamin. (1998). Islamic Theology: Traditionalism and Rationalism. Edinburgh: Edinburgh University Press.

Ahmad, Kassim. (2012). Islamic Renaissance: A New Era Has Started. Rainbow Press, U.S.A..

Ahmad Kassim, (9 November 1985). Ijtihad dan Pembaharuan Pemikiran Islam. Tiada Terbitan.

Ali, Ameer. (1880). The Personal Law of The Mahommedans. (According to All The Schools.) Together with A Comparative Sketch of The Law of Inheritance among The Sunnis and The Shiahs. London: W. H. Allen \& Co..

Ali, Ameer. (1902). Spirit of Islam Life and Teachings of Mohammed. Calcutta: S. K. Lahiri. Co..

Ali, Ameer. (1906). Islamic. London: Archibald Constable \& CO Ltd.

Ali, Ameer. (1977). Short History of The Saracens Being An Account of The Rise and Decline of The Saracenic Power and of The Economic, Social Andra. New Delhi: Kitab Bhawan.

Ali, Ameer. (1978). Islamic History and Culture. New Delhi: Amar Prakashan.

Arbi, Muslim. (1989). Rasionalitas Islam. Bandar Lampung: Penerbit YAPI. 
Md Hasri / UMRAN - International Journal of Islamic and Civilizational Studies. vol. 4, no.3 (2017) 01-10

Bennett, Joshua. (2015). A History of "Rationalism" in Victorian Britain, Modern Intellectual History. Cambridge University Press.

Fjordman, Islam. (2007). The Greeks and The Scientific Revolution. Assyrian International News Agency.

Guthrie, Shandon. (2002). Rationalism and the Historical Mind/Body Controversy. Quodlibet Journal 4 (2-3).

Leslie, Armour \&James, Bradley. (1996). Philosophy after F.H. Bradley. A\&C Black.

Nasution, Harun. (1975). Pembaharuan dalam Islam: Sejarah Pemikiran dan Gerakan. Jakarta: PT. Bulan Bintang.

Nasution, Harun. (1995). Islam Rasional: Gagasan dan Pemikiran. Bandung : Mizan.

Nasution, Harun. (2013). Teologi Islam: Aliran-Aliran Sejarah Analisa Perbandingan. Penerbit Universitas Indonesia..

Stoddard, Lothrop. (1921). The New World of Islam World of Islam. London: Charles Scribner Sons.

al-Syahrastani. (t.t). Kitab Al-Milal Wa 'L-Nihal (Book of Sects and Creeds). Tiada Terbitan. 